Received: 07-12-2019

(Date-Month-Year)
Revised: 22-01-2020

(Date-Month-Year)
Published: 20-04-2020

(Date-Month-Year)

\title{
EFEKTIVITAS KEMAMPUAN BERPIKIR KRITIS MELALUI MODEL COLLABORATIVE LEARNING DENGAN MEDIA BLOG PADA MATAKULIAH KALKULUS II
}

\author{
Sunismi $^{1}$, Abdul Halim Fathani ${ }^{2}$, Muhammad Baidawi ${ }^{3}$ \\ 1,2 Pendidikan Matematika FKIP, Universitas Islam Malang, Indonesia \\ ${ }^{3}$ Pendidikan Matematika FKIP, Universitas Wisnuwardhana Malang, Indonesia \\ ${ }^{1}$ sunismiunisma@yahoo.com \\ ${ }^{2}$ fathani@unisma.ac.id, \\ 33baidawi_muhammad@ymail.com
}

\begin{abstract}
Abstrak: Tujuan penelitian ini untuk mengetahui hasil uji efektivitas penerapan model pembelajaran collaborative learning dengan media blog terhadap kemampuan berpikir kritis mahasiswa pada matakuliah kalkulus II. Metode penelitian menggunakan quasi-eksperimental dengan jenis perancangan pretest-posttest nonequivalent control group. Teknik analisis data yang digunakan adalah independent sample t-test melalui program SPSS 16.0 for Windows. Sampel penelitian ini adalah mahasiswa semester dua dari Unidha dan Unisma yang berjumlah 118 mahasiswa. Hasil penelitian ini didasarkan pada hasil uji t, menggunakan Independent Sample T-Test untuk data postes di Unisma diperoleh nilai signifikansi (sig. 2-tailed) sebesar 0,049 dan di Unidha sebesar 0,045, karena keduanya lebih kecil dari 0,05, dapat disimpulkan bahwa kemampuan berpikir kritis matakuliah kalkulus II antara kelompok eksperimen dan kontrol berbeda secara signifikan. Sedangkan nilai rata-rata postes pada kelompok eksperimen sebesar 63.67, dan nilai rata-rata kelompok kontrol sebesar 53.43, demikian juga nilai rata-rata pada kelompok eksperimen sebesar 65.83, dan kelompok kontrol sebesar 60.04. Berdasarkan nilai rata-rata postes tersebut diperoleh bahwa masing-masing nilai rata-rata pada kelompok eksperimen lebih besar daripada nilai rata-rata kelompok kontrol, maka dapat disimpulkan kemampuan berpikir kritis matakuliah kalkulus II antara kelompok eksperimen lebih baik dibandingkan kelompok kontrol.
\end{abstract}

Katakunci: kemampuan berpikir kritis; model collaborative learning; media blog; kalkulus II

\begin{abstract}
The purpose of this study was to determine the results of the effectiveness of the implementation of collaborative learning models with blog media on the critical thinking abilities of students in calculus II. The research method uses quasi-experimental with the type of pretest-posttest nonequivalent control group design. While the data analysis technique used is independent sample t-test through the SPSS 16.0 for Windows program, by first conducting the Lilliefors normality test (Kolmogorov-Smirnov) and the Levene's test (homogeneity test). The sample in this study were second semester students from Unidha and Unisma, 118 students. The results of this study are based on the results of the t test, using the Independent Sample T-Test for posttest data at Unisma, the significance value (sig. 2-tailed) was 0.049 and at Unidha was 0.045 , because both smaller than 0.05 , it can be concluded that the critical thinking ability of calculus II, between the experimental group and the control group is significantly different. While the posttest average score of the experimental group was 63.67, and the control group was 53.43, as well as the average scores of the experimental group at 65.83 , and the control group was 60.04 . Based on the posttest average values obtained that each average value in the experimental group is greater than the average value of the control group in both samples, it can be concluded the critical thinking ability of calculus II between the experimental group is better than the control group.
\end{abstract}

Keywords: critical thinking ability; collaborative learning model; blog media; calculus II 


\section{Pendahuluan}

Dalam matematika berisi konten berupa ilmu yang mendasari perkembangan teknologi modern sehingga berperan penting dalam mengembangkan daya pikir manusia. Melalui mata pelajaran matematika peserta didik dapat dibekali dengan berbagai kemampuan, antara lain kemampuan berpikir logis, berpikir analitis, berpikir sistematis, berpikir kritis, dan berpikir kreatif, serta kemampuan bekerja sama (Permendiknas, 2006).

Mahasiswa yang menempuh program studi pendidikan matematika, wajib menempuh matakuliah Kalkulus II. Kalkulus II merupakan bagian dari matematika yang banyak menekankan pada pemahaman mahasiswa tentang konsep, teorema, dan algoritma secara intuitif. Dengan demikian, matakuliah kalkulus II tidak lepas dari kegiatan belajar tentang konsep-konsep, pembuktian teorema secara deduktif, dan penyelesaian masalah secara algoritma. Bila dilakukan pembelajaran secara konvensional melalui pembuktian konsep Kalkulus II yang sangat abstrak akan menjadikan mahasiswa banyak mengelami kesulitan. Sehingga menjadikan pelajaran ini sulit dan membosankan.

Sistem pembelajaran yang digunakan dosen akan berdampak terhadap pemahaman konsep dan kemampuan berpikir mahasiswa. Hal ini sesuai dengan pernyatan Hadi (2007), bahwa sistem pembelajaran yang dilakukan pada hampir semua program studi pada suatu perguruan tinggi di Indonesia masih bersifat monoton satu arah, yaitu transfer materi oleh dosen dengan cara menjelaskan, hal ini juga sering dilakukan pada pembelajaran matakuliah Kalkulus II. Sistem pembelajaran yang sering dilakukan tersebut lebih dikenal dengan model pembelajaran yang berpusat pada dosen (teacher-centered learning), yang dapat menjadikan mahasiswa pasif dan tidak kreatif. Dengan demikian, mahasiswa akan mendapatkan materi yang bersifat abstrak yang tidak mereka ketahui untuk apa materi itu dipelajari. Hal ini membuat mahasiswa mengalami kesulitan dalam mempelajari, sehingga kesulitan mencapai hasil belajar secara maksimal.

Agar mahasiswa dapat meningkatkan hasil belajar secara optimal, diperlukan pembelajaran yang dapat memberikan kebebasan mahasiswa untuk berpikir dalam menyampaikan ide. Salah satu sistem pembelajaran dengan menggunakan model pembelajaran yang dapat mewujudkan pencapaian hasil belajar mahasiswa secara optimal, yaitu melalui penerapan model collaborative learning (model pembelajaran kolaboratif) (Syukur, 2004).

Collaborative learning models merupakan suatu model pembelajaran yang dilakukan dengan cara berkolaborasi atau kerjasama antar mahasiswa yang didasarkan pada kemampuan yang dibangun sendiri oleh anggota kelompok. Hal ini sesuai dengan pernyataan Marjan Laal (2012) dan (MacGregor. 1990) yang menyatakan bahwa collaborative learning models is educational approach to teaching and learning that involves groups of students work together to solve problems, complete tasks, and make products. Oleh karena itu melalui model collaborative learning, mahasiswa diberi kesempatan untuk bersosialisasi dengan teman sebaya dalam kelompok, sehingga dapat berekspresi dalam mempertahankan ide, bertukar ide, mengajukan pertanyaanpertanyaan dan kerangka kerja pemikiran lainnya, serta dapat terlibat secara aktif dalam kelompoknya (Smith and MacGregor. 1992). Sedangkan tugas dosen sebagai fasilitator ketika mahasiswa bekerja untuk menemukan konsep-konsep atau prinsip-prinsip. Bila pembelajaran 
seperti itu dilakukan akan dapat menimbulkan antusiasme dan motivasi belajar, menumbuhkan kemampuan berpikir kritis, mengasah keterampilan bereksplorasi; serta menumbuhkan kemandirian untuk memecahkan masalah yang baik pada diri mahasiswa.

Melalui penerapan model pembelajaran collaborative learning diharapkan setiap anggota kelompok dituntut untuk berada dalam situasi konflik intelektual berdasarkan kemampuan pada masing-masing anggota kelompok, baik bersama anggota kelompok maupun dengan anggota kelompok lain. Aktivitas model pembelajaran collaborative learning harus mengutamakan pencapaian dan kualitas dalam pemecahan masalah, kemampuan berpikir kritis, memaksimalkan hubungan antar pribadi dalam kelompok, dan keselarasan dalam bekerja. Sedangkan penilaian berdasarkan pada kemampuan setiap anggota secara individu maupun kelompok (Hosnan, 2014).

Model pembelajaran collaborative learning merupakan suatu model pembelajaran berkelompok dengan menerapkan media internet sebagai media pembelajaran yang menempatkan mahasiswa aktif di dalam kelas maupun aktif melalui media blog dengan cara membentuk sebuah kelompok diskusi baik di kelas maupun diskusi secara online melalui media blog. Pembentukan kelompok diskusi untuk bekerja sama dalam memecahkan masalah dan saling menunjukkan kemampuan sehingga kemampuan berfikir kritis mahasiswa dapat tercapai. Dimana kemampuan berpikir kritis merupakan kemampuan mahasiswa untuk menggunakan potensi kecerdasan mereka, menyelesaikan masalah, merasionalisasi dan empiris, dapat memfasilitasi hubungan sebab akibat, mampu memberikan logika yang dapat diterima oleh pikiran orang lain, dan semua sesuai dengan data (Schneider. 2002) dan (Ennis,. 1996). Oleh karena itu agar kemampuan berpikir kritis mahasiswa dapat tercapai secara optimal, maka diperlukan pembelajaran yang dapat memberikan kebebasan mahasiswa untuk menuangkan kemampuan berpikir kritisnya melalui kegiatan diskusi secara kolaboratis dengan anggota kelompoknya.

Implementasi model collaborative learning dapat dilakukan dengan baik ketika dikombinasikan dengan media pembelajaran yang tepat sehingga dapat memudahkan mahasiswa dalam belajar. Bila model collaborative learning dikombinasikan dengan media internet, maka akan menjadikan kegiatan pembelajaran yang lengkap. Dimana media internet merupakan salah satu bagian dari pembelajaran e-learning. Perubahan konsep pembelajaran dari konvensional ke e-learning harus dilakukan dengan melibatkan strategi pengembangan akademik yang tepat (Welsh \& Brown, 2003 dan Khatimi, 2006). Menurut pernyataan Welsh\&Brown, dan Khatimi, bahwa pembelajaran e-learning memiliki beberapa keunggulan, antara lain: (a) mahasiswa dapat mengembangkan kemampuan berpikir mereka, (b) mahasiswa dapat melakukan pembelajaran secara interaktif, dan (c) mahasiswa dapat menyelesaikan tugas lebih beragam dan lebih cepat. Karena $e$ learning merupakan pembelajaran dengan memanfaatkan teknologi komputer atau jaringan internet. $E$ learning merupakan suatu pemebelajaran dengan memanfaatkan teknologi komputer dengan media internet. Hal ini bisa dilakukan kegiatan belajar melalui tempat masing-masing tanpa harus secara fisik bertatap muka. Sistem pembelajaran elektronik merupakan cara baru dalam proses pembelajaran. Oleh karena itu, internet dapat digunakan sebagai media 
pembelajaran, sehingga internet menjadi populer karena merupakan media yang tepat untuk mendapatkan informasi terbaru dengan berbagai variasi dengan lebih cepat dan lebih mudah (Oetomo, 2002).

Salah satu model pembelajaran dengan memanfaatkan media internet yaitu model pembelajaran dengan bantuan media blog. Di dalam media blog dapat menampilkan publikasi secara online dengan cepat dan dapat mengundang pembaca untuk memberikan umpan balik sebagai komentar (Herutomo, 2010 dan Subianto. 2009). Media blog merupakan media dalam bentuk aplikasi web yang berisi konten tulisan-tulisan (yang dimuat sebagai postingan) pada sebuah halaman web. Selain itu, pengunjung media blog juga dapat memberikan komentar terkait konten tulisan pemilik blog. Jadi media pembelajaran berbasis blog merupakan sebuah media dengan memanfaatkan situs web secara online dengan menggunakan perangkat lunak yang memudahkan pengguna atau pembaca. Melalui media blog dapat membantu memudahkan proses pembelajaran sehingga lebih menarik. Pembelajaran dengan media blog membutuhkan kocakapan dari dosen untuk dapat mengoperasikannya dalam proses pembelajaran. Menurut Campbell (2003) menyatakan bahwa weblogs menyediakan ruang komunikasi yang dapat digunakan oleh dosen dan mahasiswa untuk mengembangkan kemampuannya dalam berbagi ide, dan merefleksikan pekerjaan yang dilakukan di kelas.

Kalkulus II merupakan matakuliah yang dapat memberikan pengetahuan, wawasan, dan keterampilan pada mahasiswa yang lebih mendalam mengenai konsep anti turunan (integral tak tentu), aplikasi integral, metode pengintegralan, dan integral bentuk tak tentu serta penerapan integral dalam berbagai bidang selain matematika. Selain itu kalkulus II merupakan matakuliah prasyarat untuk mempelajari matakuliah yang lain, seperti kalkulus lanjut, persamaan diferensial, dan statistika matematika. Oleh karena itu, agar mahasiswa dapat memahami kalkulus II dengan baik, maka dosen perlu melakukan proses pembelajaran yang dapat memudahkan mahasiswa memahami konsep-konsep materi kalkulus II. Salah satunya dengan model collaborative learning dengan media blog. Model collaborative learning dengan media blog merupakan model pembelajaran berkelompok setiap anggota menyumbangkan kemampuan berpikir, pengalaman, ide, sikap, pendapat, kemampuan dan keterampilan yang dimilikinya melalui media online blogspot. Sehingga dapat bertatap muka secara online melalui blog untuk secara bersama-sama saling bertukar pikiran dan meningkatkan pemahaman seluruh anggota.

Berdasarkan uraian di atas, jika model pembelajaran collaborative learning matematika dikombinasikan dengan media blog untuk pembelajaran kalkulus II yang terstruktur dengan baik, maka akan menjadi model pembelajaran matematika yang sistematis, efektif, efisien, dan menyenangkan dengan harapan dapat meningkatkan kemampuan berpikir kritis mahasiswa secara optimal (Reid. 2004 dan Gokhale. 1995). Oleh karena itu, penulis bermaksud untuk mendeskripsikan hasil uji efektivitas penerapan model pembelajaran collaborative learning matematika melalui media blog pada matakuliah kalkulus II. Sehingga akan dapat diketahui bahwa model pembelajaran collaborative learning matematika melalui media blog merupakan model pembelajaran menyenangkan yang dapat mengoptimalkan kemampuan berpikir mahasiswa dalam matakuliah kalkulus II. 


\section{Metode Penelitian}

Metode dalam penelitian ini menggunakan penelitian kuantitatif dengan jenis penelitian quasieksperimental atau quasi-eksperimental research, serta jenis rancangannya adalah pretest-posttest nonequivalent control group (Sugiono. 2010). Sedangkan teknik analisis data penelitian yang digunakan adalah independent sample t-test melalui program SPSS 16, dengan terlebih dahulu melakukan uji prasyarat, yaitu uji Lilliefors (Kolmogorov-Smirnov) untuk uji normalitas dan uji Levene's untuk uji homogenitas.

Dalam penelitian ini, populasi yang digunakan adalah seluruh mahasiswa semester II di Unidha yang terdiri dari 2 kelas yang berjumlah 64 mahasiswa dan di Unisma yang terdiri dari 3 kelas yang berjumlah 105 mahasiswa. Sedangkan sampel dalam penelitian ini dengan menggunakan teknik cluster random sampling yang mana pengambilan sampelnya mengacu pada kelompok, bukan individu. Pada masing-masing perguruan tinggi yaitu Unidha dan Unisma diambil 2 kelas sebagai kelompok sampel dalam penelitian ini. Oleh karena itu sampel di Unidha terpilih 2 kelas, yaitu berjumlah 50 mahasiswa. Sedangkan di Unisma juga diambil 2 kelas, yaitu kelas A dan Kelas B yang berjumlah 68 mahasiswa. Sehingga sampel dalam penelitian ini semua berjumlah 118 mahasiswa.

Teknik pengumpulan data dalam penelitian ini menggunakan teknik tes untuk memperoleh data pretes dan data postes. Jenis data adalah data kuantitatif, yaitu data nilai hasil tes kemampuan berpikir kritis mahasiswa, yaitu pretes dan postes. Sedangkan instrumen yang digunakan dalam penelitian ini berupa soal tes kemampuan berpikir kritis, bentuk soal tes essay untuk mengukur kemampuan berpikir kritis mahsiswa.

\section{Hasil Dan Pembahasan}

Hasil analisis data dalam penelitian ini secara lengkap dipaparkan sebagai berikut:

\section{Analisis Data Pretes}

\section{(1) Nilai Rata-rata dan Simpangan Baku}

Data pretes untuk mengetahui kemampuan awal pada kelompok eksperimen dan kontrol. Nilai yang digunakan untuk menilai pretes ini menggunakan rentang nilai 0-100. Teknik analisis data pretes untuk masing-masing kelas sampel, yaitu diperoleh nilai rerata dan simpangan baku seperti terlihat pada Tabel 1 dan Tabel 2 berikut ini.

Tabel 1: Rerata dan Simpangan Baku dari Data Pretes Kelompok Sampel di Unisma Malang

\begin{tabular}{c|c|c|c|c|c}
\hline & $\begin{array}{c}\text { Model } \\
\text { Pembe } \\
\text { lajaran }\end{array}$ & $\mathrm{N}$ & Mean & SD & $\begin{array}{c}\text { Std. Error } \\
\text { Mean }\end{array}$ \\
\hline Pretes & $\mathrm{CL}$ & 33 & 49.0000 & 19.85888 & 3.45699 \\
\cline { 2 - 6 } & $\mathrm{K}$ & 35 & 51.2571 & 24.07872 & 4.07005 \\
\hline
\end{tabular}

Tabel 2: Rerata dan Simpangan Baku dari Data Pretes Kelompok Sampel di Unidha Malang

\begin{tabular}{c|c|c|c|c|c}
\hline & $\begin{array}{c}\text { Model } \\
\text { Pembel } \\
\text { ajaran }\end{array}$ & $\mathrm{N}$ & Mean & SD & $\begin{array}{c}\text { Std. Error } \\
\text { Mean }\end{array}$ \\
\hline Pretes & $\mathrm{CL}$ & 24 & 60.3750 & 8.52522 & 1.74020 \\
\cline { 2 - 6 } & $\mathrm{K}$ & 26 & 57.3846 & 8.66292 & 1.69894 \\
\hline
\end{tabular}

\section{(2) Uji Normalitas}

Uji normalitas untuk mengetahui data pretes berasal dari populasi yang berdistribusi normal atau tidak. Uji normalitas menggunakan uji Lilliefors (Kolmogorov-Smirnov) normality test dengan menggunakan program SPSS 16.0 for Windows dengan taraf signifikansi 0,05 . Tampilan output dapat dilihat pada Tabel 3 dan Tabel 4 berikut ini.

Tabel 3: Uji Normalitas Distribusi Data Pretes Kelompok Sampel di Unisma Malang

\begin{tabular}{|c|c} 
Model & The Kolmogorov Smirnov \\
Pembela & Normality Test \\
\hline
\end{tabular}




\begin{tabular}{l|c|r|r|r}
\hline & jaran & Statistic & \multicolumn{1}{c|}{ df } & \multicolumn{2}{c}{ Sig. } \\
\hline \multirow{2}{*}{ Pretes } & $\mathrm{CL}$ & .134 & 33 & .137 \\
\cline { 2 - 5 } & $\mathrm{K}$ & .125 & 35 & .186 \\
\hline
\end{tabular}

Tabel 4: Uji Normalitas Data Pretes Kelompok Sampel di Unidha Malang

\begin{tabular}{c|c|r|r|r}
\hline \multirow{2}{*}{$\begin{array}{c}\text { Model } \\
\text { Pembela } \\
\text { jaran }\end{array}$} & \multicolumn{4}{|c}{$\begin{array}{r}\text { The Kolmogorov Smirnov } \\
\text { Normality Test }\end{array}$} \\
\cline { 3 - 5 } & Statistic & \multicolumn{1}{c}{ df } & \multicolumn{1}{c}{ Sig. } \\
\hline Pretes & $\mathrm{CL}$ & .171 & 24 & .066 \\
\cline { 2 - 5 } & $\mathrm{K}$ & .164 & 26 & .070 \\
\hline
\end{tabular}

Berdasarkan hasil output SPSS 16.0 for windows bahwa uji normalitas untuk data pretes di Unisma Malang, seperti pada Tabel 3 diperoleh nilai sig.: 0,137 pada kelompok eksperimen dan 0,186 kelompok kontrol lebih besar dari 0,05 , maka $H_{0}$ diterima. Hal ini berarti sampel Unisma Malang dari kelompok eksperimen dan kontrol berasal dari populasi berdistribusi normal. Demikian juga hasil output uji normalitas untuk data pretes di Unidha Malang, seperti pada Tabel 4 diperoleh nilai sig. : 0,66 pada kelompok eksperimen dan 0,70 kelompok kontrol lebih besar dari 0,05, maka $H_{0}$ diterima. Hal ini berarti sampel Unidha Malang dari kelompok eksperimen dan kontrol berasal dari populasi berdistribusi normal.

\section{(3) Uji Homogenitas}

Setelah diketahui sampel berasal dari populasi berdistribusi normal, maka dilakukan uji homogenitas menggunakan uji Levene's dengan taraf signifikansi 0,05 . Setelah dilakukan pengolahan data, diperoleh hasil output seperti terlihat Tabel 5 dan Tabel 6 berikut ini.

Tabel 5: Uji Homogenitas Data Pretes Kelompok Sampel di Unisma Malang

\begin{tabular}{|c|c|c|c|}
\hline Data pretes & The & Sig. & Keterangan \\
\hline $\begin{array}{c}\text { Eksperimen } \\
\text { dan } \\
\text { Kontrol }\end{array}$ & $\begin{array}{l}\text { Levenes } \\
\text { Test for } \\
\text { Equality of } \\
\text { Variances }\end{array}$ & .090 & $H_{0}$ diterima \\
\hline
\end{tabular}

Ket.: Jika nilai Sig pada uji Lavene Statistic > 0,05 , maka $H_{0}$ diterima dan data pretes homogen
Tabel 6: Uji Homogenitas Data Pretes Kelompok Sampel di Unidha Malang

\begin{tabular}{lcccc} 
& The & Sig. & Keterangan \\
\cline { 2 - 4 } Data pretes & $\begin{array}{c}\text { Levene's } \\
\text { Eksperimen }\end{array}$ & Test for & & \\
dan Kontrol & $\begin{array}{c}\text { Equality of } \\
\text { Variances }\end{array}$ & .844 & $H_{0}$ diterima \\
& & &
\end{tabular}

Ket.: Jika nilai Sig pada uji Lavene Statistic > 0,05 , maka $H_{0}$ diterima dan data pretes homogen

Berdasarkan hasil output uji homogenitas seperti pada Tabel 5 untuk data pretes di Unisma Malang, diperoleh nilai sig. $=0,090$ lebih besar dari 0,05 maka $\mathrm{H}_{\mathrm{o}}$ diterima, sehingga dapat disimpulkan bahwa tidak terdapat perbedaan varians antara varians antara kelompok eksperimen dan kelompok kontrol atau varians antara kelompok eksperimen dan kelompok kontrol adalah homogen. Demikian juga hasil output uji homogenitas pada Tabel 6 untuk data pretes di Unidha Malang, diperoleh nilai sig. $=0,844$ lebih besar dari 0,05 maka $\mathrm{H}_{\mathrm{o}}$ diterima, sehingga dapat disimpulkan bahwa tidak terdapat perbedaan varians antara varians antara kelompok eksperimen dan kelompok kontrol atau varians antara kelompok eksperimen dan kelompok kontrol adalah homogen.

\section{(4) Uji Kesamaan Rata-rata}

Berdasarkan hasil uji normalitas dan uji homogenitas, diperoleh bahwa data pretes memenuhi uji prasyarat, yaitu data pretes berdistribusi normal dan homogen, sehingga dilanjutkan uji kesamaan rata-rata menggunakan uji $\mathrm{t}$ dua pihak. Dengan menggunakan Independent Sample T-Test pada taraf signifikansi 0,05 . Setelah dilakukan analisis data pretes, sehingga diperoleh hasil uji t dapat dilihat pada Tabel 7 dan Tabel 8, berikut ini.

Tabel 7: Uji-t Data Pretes Kelompok Sampel di Unisma Malang

\begin{tabular}{ccc}
\hline \multirow{2}{*}{$\begin{array}{c}\text { Equal variances } \\
\text { asumed }\end{array}$} & Sig. (2-tailed) & Keterangan \\
\cline { 2 - 3 } & .676 & $H_{0}$ diterima
\end{tabular}


Keterangan: Jika nilai Sig pada uji t-test Equality of Means $>0,05$, maka $H_{0}$ diterima

Tabel 8: Uji-t Data Pretes Kelompok Sampel di Unidha Malang

\begin{tabular}{ccc} 
Equal variances & Sig. (2-tailed) & Keterangan \\
\cline { 2 - 3 } \begin{tabular}{c} 
asumed \\
\cline { 2 - 3 }
\end{tabular} & .225 & $H_{0}$ diterima
\end{tabular}

Keterangan: Jika nilai Sig pada uji t-test Equality of Means $>0,05$, maka $H_{0}$ diterima

Berdasarkan hasil output uji Independent Sample T-Test untuk data pretes di Unisma Malang, seperti pada Tabel 7 terlihat bahwa nilai sig.2-tailed $=$ $0,676>0,05$, maka $H_{0}$ diterima. Kesimpulan bahwa kemampuan berpikir kritis mahasiswa kelompok eksperimen (model collaborative learning) dan kelompok kontrol (model konvensional) data pretes tidak berbeda secara signifikan. Demikian juga hasil output uji Independent Sample T-Test untuk data pretes di Unisma Malang, seperti pada Tabel 8 terlihat bahwa nilai sig.2-tailed $=$ $0,225>0,05$ maka $H_{0}$ diterima. Kesimpulan bahwa kemampuan berpikir kritis mahasiswa kelompok eksperimen (model collaborative learning) dan kelompok kontrol (model konvensional) data pretes tidak berbeda secara signifikan.

\section{Analisis Data Postes}

Dalam penelitian ini kelompok sampel di Unisma dan Unidha, pada kelas eksperimen diberi perlakuan dengan menerapkan model pembelajarn collaborative learning dengan media blog dengan alamat blog adalah https://sunismikalkulus.blogspot.co.id/?m $=0$, sedangkan kelompok kontrol menggunakan model konvesional.

\section{(1) Nilai Rata-rata dan Simpangan Baku}

Data postes untuk mengetahui kemampuan berpikir kritis mahasiswa pada kelompok eksperimen dan kelompok kontrol berbeda atau sama. Nilai postes memiliki rentang 0-100. Dari hasil pengolahan data postes untuk masing-masing kelas, yaitu kelompok eksperimen dan kelompok kontrol, diperoleh nilai rerata dan simpangan baku seperti terlihat pada Tabel 9 dan Tabel 10 berikut ini.

Tabel 9: Rerata dan Simpangan Baku dari Data Postes Kelompok Sampel di Unisma Malang

\begin{tabular}{c|c|c|c|c|c}
\hline & $\begin{array}{c}\text { Model } \\
\text { Pembe } \\
\text { lajaran }\end{array}$ & $\mathrm{N}$ & Mean & $\begin{array}{c}\text { Std. } \\
\text { Deviation }\end{array}$ & $\begin{array}{c}\text { Std. } \\
\text { Error } \\
\text { Mean }\end{array}$ \\
\hline Postes & $\mathrm{CL}$ & 33 & 63.6667 & 19.07496 & 3.32052 \\
\cline { 2 - 6 } & $\mathrm{K}$ & 35 & 53.4286 & 22.74576 & 3.84474 \\
\hline
\end{tabular}

Tabel 10: Rerata dan Simpangan Baku dari Data Postes Kelompok Sampel di Unidha Malang

\begin{tabular}{c|c|c|c|c|c}
\hline & $\begin{array}{c}\text { Model } \\
\text { Pembel } \\
\text { ajaran }\end{array}$ & $\mathrm{N}$ & Mean & $\begin{array}{c}\text { Std. } \\
\text { Deviation }\end{array}$ & $\begin{array}{c}\text { Std. } \\
\text { Error } \\
\text { Mean }\end{array}$ \\
\hline \multirow{2}{*}{ Postes } & $\mathrm{CL}$ & 24 & 65.8333 & 8.69116 & 1.77408 \\
\cline { 2 - 6 } & $\mathrm{K}$ & 26 & 60.0385 & 10.97080 & 2.15155 \\
\hline
\end{tabular}

\section{(2) Uji Normalitas}

Uji normalitas terhadap dua kelompok tersebut dilakukan dengan uji Lilliefors (Kolmogorov-Smirnov) normality test dengan menggunakan program SPSS 16.0 for Windows dengan taraf signifikansi 0,05. Setelah dilakukan pengolahan data, tampilan output dapat dilihat pada Tabel 11 dan Tabel 12 berikut ini.

Tabel 11: Uji Normalitas Data Postes Kelompok Sampel di Unisma Malang

\begin{tabular}{|c|c|c|c|c|}
\hline & \multirow{2}{*}{$\begin{array}{l}\text { Model } \\
\text { Pembe } \\
\text { lajaran }\end{array}$} & \multicolumn{3}{|c|}{$\begin{array}{c}\text { The Kolmogorov Smirnov } \\
\text { Normality Test }\end{array}$} \\
\hline & & Statistic & $\mathrm{df}$ & Sig. \\
\hline \multirow[t]{2}{*}{ Postes } & $\mathrm{CL}$ & .142 & 33 & .089 \\
\hline & $\mathrm{K}$ & .126 & 35 & 179 \\
\hline
\end{tabular}

Tabel 12: Normalitas Data Postes Kelompok Sampel di Unidha Malang

\begin{tabular}{|c|c|c|c|}
\hline \multirow{2}{*}{$\begin{array}{l}\text { Model } \\
\text { Pembe } \\
\text { lajaran }\end{array}$} & \multicolumn{3}{|c|}{$\begin{array}{c}\text { The Kolmogorov Smirnov } \\
\text { Normality Test }\end{array}$} \\
\hline & Statistic & df & Sig. \\
\hline
\end{tabular}




\begin{tabular}{l|c|r|r|r}
\hline Postes & $\mathrm{CL}$ & .121 & 24 & $.200^{*}$ \\
\cline { 2 - 5 } & $\mathrm{K}$ & .148 & 26 & .150 \\
\hline
\end{tabular}

Berdasarkan hasil output uji normalitas dengan menggunakan uji Lilliefors (Kolmogorov-Smirnov) normality test untuk data postes di Unisma Malang, seperti pada Tabel 11 diperoleh nilai sig. $=0,089$ pada kelompok eksperimen dan 0,179 kelompok kontrol lebih besar dari 0,05, maka berdasarkan $H_{0}$ diterima. Hal ini berarti sampel Unisma Malang dari kelompok eksperimen dan kelompok kontrol berasal dari populasi yang berdistribusi normal. Demikian juga hasil output uji normalitas untuk data postes di Unidha Malang, seperti pada Tabel 12 diperoleh nilai sig. $=0,200$ pada kelompok eksperimen dan 0,150 kelompok kontrol lebih besar dari 0,05, maka $H_{0}$ diterima. Hal ini berarti sampel Unidha Malang dari kelompok eksperimen dan kelompok kontrol berasal dari populasi yang berdistribusi normal.

\section{(3) Uji Homogenitas}

Uji homogenitas menggunakan statistik uji Levene's dengan bantuan program SPSS 16.0 for Windows dengan taraf signifikansi 0,05. Hal ini dilakukan untuk melihat apakah data berasal dari variansi yang sama atau tidak. Setelah dilakukan pengolahan data, tampilan output dapat dilihat pada Tabel 13 dan Tabel 14 berikut ini.

Tabel 13: Uji Homogenitas Data Postes Kelompok Sampel di Unisma Malang

\begin{tabular}{|c|c|c|c|}
\hline & The & Sig. & Keterangan \\
\hline $\begin{array}{l}\text { Eksperimen } \\
\text { dan Kontrol }\end{array}$ & $\begin{array}{l}\text { Test for } \\
\text { Equality of } \\
\text { Variances }\end{array}$ & .156 & $H_{0}$ diterima \\
\hline
\end{tabular}

Ket.: Jika nilai Sig pada uji Lavene Statistic > 0,05 , maka $H_{0}$ diterima dan data pretes homogen

Tabel 14: Homogenitas Data Postes Kelompok Sampel di Unidha Malang

\begin{tabular}{cccc}
\hline & The Levene's & Sig. & Keterangan \\
\cline { 3 - 4 } Data pretes & Test for & & $H_{0}$ \\
Eksperimen & $\begin{array}{c}\text { Equality of } \\
\text { dan Kontrol }\end{array}$ & .528 & diterima \\
& Variances & &
\end{tabular}

Ket.: Jika nilai Sig pada uji Lavene Statistic > 0,05 , maka $H_{0}$ diterima dan data pretes homogen

Berdasarkan hasil output uji Levene's pada Tabel 13 untuk data postes di Unisma Malang, diperoleh nilai sig. = 0,156 , lebih besar dari 0,05 , sehingga $\mathrm{H}_{\mathrm{o}}$ diterima, maka dapat disimpulkan bahwa tidak terdapat perbedaan varians antara varians antara kelompok eksperimen (model collaborative learning) dan kelompok kontrol (model konvensional) atau varians antara kelompok eksperimen dan kelompok kontrol adalah homogen. Demikian juga hasil output uji Levene's pada Tabel 14 untuk data postes di Unidha Malang, diperoleh nilai sig. = 0,528, lebih besar dari 0,05, sehingga $\mathrm{H}_{\mathrm{o}}$ diterima, maka dapat disimpulkan bahwa tidak terdapat perbedaan varians antara varians antara kelompok eksperimen (model collaborative learning) dan kelompok kontrol (model konvensional) atau varians antara kelompok eksperimen dan kelompok kontrol adalah homogen.

\section{(4) Uji Independent Sample T-Test Data Postes}

Selanjutnya dilakukan uji hipotesis dengan menggunakan uji t dua pihak melalui program SPSS 16.0 for Windows menggunakan Independent Sample T-Test dengan taraf signifikansi 0,05 . Setelah dilakukan pengolahan data, hasil uji t dapat dilihat pada Tabel 15 dan Tabel 16, berikut ini.

Tabel 15: Uji-t Data Postes Kelompok Sampel di Unisma Malang

\begin{tabular}{ccc}
\multirow{2}{*}{$\begin{array}{c}\text { Equal variances } \\
\text { asumed }\end{array}$} & Sig. (2-tailed) & Keterangan \\
\cline { 2 - 3 } & .049 & $H_{0}$ ditolak
\end{tabular}

Keterangan: Jika nilai Sig pada uji $t$-test Equality of Means $<0,05$, maka $H_{0}$ ditolak dan ada perbedaan hasil posttest kelas eksperimen dan kontrol

Pi: Mathematics Education Journal 
Tabel 16 : Uji-t Data Postes Kelompok Sampel di Unidha Malang

\begin{tabular}{ccc}
\hline \multirow{2}{*}{$\begin{array}{c}\text { Equal variances } \\
\text { asumed }\end{array}$} & Sig. (2-tailed) & Keterangan \\
\cline { 2 - 3 } & .045 & $H_{0}$ ditolak
\end{tabular}

Keterangan: Jika nilai Sig pada uji t-test Equality of Means $<0,05$, maka $H_{0}$ ditolak dan ada perbedaan hasil posttest kelas eksperimen dan kontrol

Berdasarkan hasil output Independent Sample T-Test untuk data postes di Unisma Malang, seperti pada Tabel 15 terlihat bahwa nilai sig.2-tailed $=0,049$ lebih kecil dari 0,05, maka $H_{0}$ diolak. Ini menunjukkan bahwa kemampuan berpikir kritis matakuliah kalkulus II mahasiswa di Unisma Malang antara kelompok eksperimen (model collaborative learning dengan media blog) dan kelompok kontrol (model konvensional) data postes berbeda secara signifikan. Sedangkan berdasarkan Tabel 9 diperoleh mean \pm SD untuk data postes di Unisma Malang pada kelompok eksperimen sebesar 82,7417, sedangkan mean \pm SD pada kelompok kontrol sebesar 76,1744. Dengan demikian dapat disimpulkan kemampuan berpikir kritis matakuliah kalkulus II mahasiswa di Unisma Malang antara kelompok eksperimen (model collaborative learning) lebih besar dibandingkan kelompok kontrol (model konvensional). Oleh karena itu kemampuan berpikir kritis matakuliah kalkulus II mahasiswa antara kelompok eksperimen (model collaborative learning) lebih baik dibandingkan kelompok kontrol (model konvensional).

Demikian juga hasil output Independent Sample T-Test untuk data postes di Unidha Malang, seperti pada Tabel 16 terlihat bahwa nilai sig.2-tailed $=0,45$ lebih kecil dari 0,05 maka $H_{0}$ ditolak. Ini menunjukkan bahwa kemampuan berpikir kritis matakuliah kalkulus II mahasiswa antara kelompok eksperimen dan kelompok kontrol data postes berbeda secara signifikan. Sedangkan berdasarkan Tabel 10 diperoleh mean \pm SD untuk data postes di Unidha Malang pada kelompok eksperimen sebesar 74,5245, sedangkan diperoleh mean $\pm \mathrm{SD}$ pada kelompok kontrol sebesar 71,0093, dengan demikian dapat disimpulkan kemampuan berpikir kritis matakuliah kalkulus II mahasiswa di Unidha Malang antara kelompok eksperimen lebih besar dibandingkan kelompok kontrol. Oleh karena itu kemampuan berpikir kritis matakuliah kalkulus II mahasiswa antara kelompok eksperimen lebih baik dibandingkan kelompok kontrol.

Pelaksanaan penelitian ini dilakukan sebanyak enam belas kali pertemuan pada kelas eksperimen dan kelas kontrol dengan alokasi waktu $2 \times$ 50 menit setiap pertemuan. Model collaborative learning dengan media blog https://sunismikalkulus.blogspot.co.id/?m $=0$ dilaksanakan pada kelas eksperimen, sedangkan model pembelajaran konvensional dilakukan pada kelas kontrol. Model collaborative learning merupakan model pembelajaran dimana mahasiswa belajar bersama secara berkelompok namun memiliki beban tugas dan tanggung jawab masing-masing untuk mencapai tujuan pembelajaran yang sama (Husain. 2012). Pelaksanaan model collaborative learning dengan media blog terdiri dari enam tahapan yakni: (1) tahap engagment, (2) tahap exploration, (3) tahap transformation, (4) tahap presentation, (5) tahap reflectio), dan (6) tahap online discussion (diskusi kolaborasi online melalui media blog).

Sedangkan

pelaksanaan

pembelajaran di kelas kontrol menggunakan model pembelajaran konvensional, yaitu pembelajaran direct instruction (metode ceramah). Model pembelajaran konvensional merupakan 
model yang memiliki karakteristik sebagai berikut pembelajaran yang berpusat pada guru (teacher center learning), mahasiswa hanya menjadi objek pembelajaran yang pasif, mahasiswa belajar mengikuti kecepatan guru, kegiatan mahasiswa yaitu mendengarkan penjelasan dosen dilanjutkan dengan mencatat intisari materi dan menghafalkannya (Zulyadaini, 2016). Dalam pelaksanaan model konvensional dilakukan dengan tahapan sebagai berikut: 1) transfer materi oleh dosen, 2) latihan soal oleh mahasiswa, 3) umpan balik oleh dosen dan mahasiswa, dan 4) latihan lanjutan oleh mahasiswa.

Kemampuan berpikir kritis yang diukur pada penelitian ini meliputi kemampuan untuk membuat pertanyaan, menganalisis masalah, memecahkan masalah, dan menyimpulkan. Berdasarkan hasil output Independent Sample T-Test untuk data postes di Unisma Malang, diperoleh nilai sig.2tailed dengan uji-t adalah 0,049. Karena nilai signifikansi kedua nilai poster baik di unisma dan Unidha Malang keduanya lebih kecil dari 0,05, maka kemampuan berpikir kritis matakuliah kalkulus II mahasiswa di Unisma Malang antara kelompok eksperimen (model collaborative learning dengan media blog) dan kelompok kontrol (model konvensional) data postes berbeda secara signifikan. Sedangkan berdasarkan nilai mean \pm SD untuk data postes di Unisma Malang pada kelompok eksperimen sebesar 82,7417, sedangkan mean \pm SD pada kelompok kontrol sebesar 76,1744. Dengan demikian dapat disimpulkan kemampuan berpikir kritis matakuliah kalkulus II mahasiswa di Unisma Malang antara kelompok eksperimen (model collaborative learning) lebih besar dibandingkan kelompok kontrol (model konvensional). Oleh karena itu kemampuan berpikir kritis matakuliah kalkulus II mahasiswa antara kelompok eksperimen (model collaborative learning) lebih baik dibandingkan kelompok kontrol (model konvensional).

Demikian juga hasil output Independent Sample T-Test untuk data postes di Unidha Malang, diperoleh nilai sig.2-tailed dengan uji-t adalah 0,45. Karena nilai signifikansi lebih kecil dari 0,05 maka kemampuan berpikir kritis matakuliah kalkulus II mahasiswa antara kelompok eksperimen (model collaborative learning) dan kelompok kontrol (model konvensional) data postes berbeda secara signifikan. Sedangkan berdasarkan nilai mean \pm SD untuk data postes di Unidha Malang pada kelompok eksperimen sebesar 74,5245, sedangkan diperoleh mean \pm SD pada kelompok kontrol sebesar 71,0093, dengan demikian dapat disimpulkan kemampuan berpikir kritis matakuliah kalkulus II mahasiswa di Unidha Malang antara kelompok eksperimen lebih besar dibandingkan kelompok kontrol. Oleh karena itu kemampuan berpikir kritis matakuliah kalkulus II mahasiswa antara kelompok eksperimen (model collaborative learning dengan media blog) lebih baik dibandingkan kelompok kontrol (model konvensional).

Berdasarkan hasil analisis Independent Sample T-Test menunjukkan bahwa model collaborative learning dengan media blog yang diterapkan dapat meningkatkan kemampuan berpikir kritis mahasiswa. Hal tersebut dikarenakan dalam model collaborative learning melibatkan beberapa mahasiswa untuk berdiskusi secara bersama-sama baik secara on line ataupun secara tatap muka dalam menyelesaikan permasalahan dan tugas yang diberikan oleh dosen dimana pembelajaran ini dapat menstimulasi kemampuan belajar mahasiswa. Kegiatan dalam model collaborative learning dapat meningkatkan kemampuan berpikir kritis melalui diskusi, mengklasifikasi pemikiran, mengevaluasi pemikiran 
orang lain, memecahkan masalah, dan menciptakan pemikiran yang baru dengan cara berkerja sama dengan orang lain.

Dalam model collaborative learning terjadi pertukaran pemikiran antar anggota dalam kelompok dimana hal ini tidak hanya meningkatkan minat belajar mahasiswa melainkan juga meningkatkan kemampuan berpikir kritis. Saling berbagi pengetahuan dalam model collaborative learning memberi peluang antar mahasiswa terlibat dalam diskusi, bertanggung jawab atas keberhasilan belajar dirinya sendiri sehingga dapat menstimulasi dirinya menjadi pemikir kritis. Menurut Thadphoothon (2005), yang menyatakan bahwa model collaborative learning dapat meningkatkan kemampuan berpikir kritis mahasiswa dalam mengembangkan ZPD (Zone Proximal Development) secara optimal bila dibantu peran dosen sebagai partner belajar dan fasilitator proses belajar. Hal ini sesuai dengan pendapat dari Cahyono (2010), menyatakan bahwa ZPD adalah jarak antara tingkat perkembangan yang ditentukan sebagai kemampuan untuk menyelesaikan masalah secara mandiri dan tingkat potensi pengembangan yang ditentukan sebagai kemampuan untuk memecahkan masalah di bawah bimbingan orang dewasa atau melalui koordinasi dengan teman yang lebih mampu.

Berdasarkan hal tersebut model collaborative learning dengan media blog mampu meningkatkan kemampuan berpikir kritis mahasiswa. Berdasarkan penelitian yang telah dilakukan maka saran yang dapat diajukan adalah sebaiknya model collaborative learning dengan media blog dilakukan secara berkelanjutan sehingga mahasiswa menjadi terbiasa dalam melakukan diskusi kelompok baik secara on line atau secara tatap muka, sehingga belajar kelompoknya dapat dilakukan secara efektif. Sebaiknya sebelum model collaborative learning dengan media blog dilakukan pengkondisian yang lebih baik kepada koordinator kelompok dalam memimpin diskusi agar mahasiswa bersama kelompoknya lebih terkoordinasi.

\section{Kesimpulan}

Berdasarkan uji efektivitas melalui penelitian quasi eksperimental diperoleh hasil bahwa data sampel kelompok eksperimen dan kelompok kontrol berasal dari populasi yang berdistribusi normal. Sedangkan hasil output uji homogenitas dengan menggunakan uji Levene's diperoleh hasil bahwa tidak terdapat perbedaan varians antara kelompok eksperimen dan kelompok kontrol atau dengan kata lain varians antara kelompok eksperimen dan kelompok kontrol adalah sama.

Berdasarkan hasil output Independent Sample T-Test untuk data postes di Unisma Malang, diperoleh nilai sig.2-tailed dengan uji-t adalah 0,049. Karena nilai sig.2-tailed kedua nilai postes baik di Unisma dan Unidha Malang keduanya lebih kecil dari 0,05, maka berdasarkan kriteria pengambilan keputusan, $H_{0} \quad$ ditolak. Sedangkan berdasarkan nilai mean \pm SD untuk data postes pada kelompok eksperimen sebesar 82,7417, sedangkan mean \pm SD pada kelompok kontrol sebesar 76,1744.

Demikian juga hasil output Independent Sample T-Test untuk data postes di Unidha Malang, diperoleh nilai sig.2-tailed dengan uji-t adalah 0,45. Karena nilai sig.2-tailed lebih kecil dari 0,05 maka berdasarkan kriteria pengambilan keputusan, $H_{0}$ diterima. Ini menunjukkan bahwa kemampuan berpikir kritis matakuliah kalkulus II mahasiswa pada kelompok eksperimen dan kelompok kontrol data postes berbeda secara signifikan.

Berdasarkan nilai mean $\pm \mathrm{SD}$ untuk data postes di Unidha Malang pada 
kelompok eksperimen sebesar 74,5245, sedangkan nilai mean \pm SD pada kelompok kontrol sebesar 71,0093, dengan demikian dapat disimpulkan kemampuan berpikir kritis kelompok eksperimen lebih besar dibandingkan kelompok kontrol. Oleh karena itu kemampuan berpikir kritis antara kelompok eksperimen lebih baik dibandingkan kelompok.

\section{DAFTAR PUSTAKA}

Cahyono, A. N. 2010. Vygotskian Perspective Proses Scaffolding untuk mencapai ZPD Peserta Didik dalam Pembelajaran Matematika. Makalah dalam Seminar Nasional Matematika dan Pendidikan Matematika. Jurusan Pendidikan Matematika FMIPA UNY, Yogyakarta, 27 November 2010.

Campbell, Aaron Patric. 2003. Weblogs for Use with ESL Classes. The Internet TESL Journal, Vol. IX, No. 2, February 2003

Chance, P. 1986. Thinking in The Classroom: Survey of Programs. New York: Columbia University.

Dillenbourg, Pierre. 1999. Collaborative Learning Cognitive and Computational Approaches. New York: Elsevier Science, Inc.

Ennis, R. H. 1996. Critical Thinking. New Jersey: Prentice Hall.

Gokhale, Anuradha A. 1995. Collaborative Learning Enhances Critical Thinking. Journal of Technology Education. Vol. 7 No. 1, Fall 1995

Hadi, Rahmini. 2007. Dari TeacherCentered Learning ke StudentCentered Learning: Perubahan Metode Pembelajaran di Perguruan Tinggi. Jurnal Pemikiran Alternatif Pendidikan, INSANIA. 12(3), 408419

Hassoubah, Zaleha Izhab. 2004. Cara Berpikir Kreatif dan Kritis
(Terjemahan dari Developing Creative \& Critical Thinking). Bandung: Nuansa.

Herutomo. 2010. Conquering Web 2.0. Jakarta: PT. Elex Media Komputindo.

Husain, Rusmin. 2012. Pengembangan Model Pembelajaran Kolaboratif dalam Meningkatkan Hasil Belajar Warga Belajar Paket C (Studi di SKB Kota Gorontalo). Universitas Pendidikan Indonesia. Repository.upi.ed

Joyce, Bruce and Weil, Marsha. 2000. Models of Teaching (Second Edition). Englewood Cliffs, New Jersey: Prentice-Hall, Inc.

Khatimi, Husnul. 2006. Mengenal ELearning Sebagai Salah Satu Bentuk Kegiatan Pembelajaran. Info Teknik. Volume 7 No. 2, Desember $2006(72-81)$

MacGregor, J.T. 1990. Collaborative Learning: Shared Inquiry as Process of Reform. San Francisco, USA : Jossey-Bass Publishing.

McGregor, Debra. 2007. Developing Thinking \& Developing Learning. Maidenhead: Open University Press. National Council of Teacher Mathematics.

Marjan, Laal 2012. Benefit of Collaborative Learning. Procedia Social and Behavioral Sciences 31 (2012) 486 - 490

Oetomo, Budi S. D. 2002. e-Education: Konsep, Teknologi Dan Aplikasi Internet Pendidikan. Yogyakarta: Andi

Permendiknas Nomor 22 Tahun 2006 tentang Kurikulum Standar Isi. Jakarta: Depdiknas. 